\title{
Availability, Nutritional Profile and Processing Level of Food Products Sold in Vending Machines in a Spanish Public University
}

\author{
Naiara Martinez-Perez ${ }^{1}(\mathbb{D})$ and Marta Arroyo-Izaga ${ }^{2, *} \mathbb{D}$ \\ 1 Department of Nursing, Faculty of Medicine and Nursing, University of the Basque Country UPV/EHU, \\ 48940 Leioa, Spain; naiara.martinez@ehu.eus \\ 2 Department of Pharmacy and Food Sciences, Faculty of Pharmacy, University of the Basque Country \\ UPV/EHU, 01006 Vitoria-Gasteiz, Spain \\ * Correspondence: marta.arroyo@ehu.eus; Tel.: +34-94-501-3862
}

Citation: Martinez-Perez, N.; Arroyo-Izaga, M. Availability, Nutritional Profile and Processing Level of Food Products Sold in Vending Machines in a Spanish Public University. Int. J. Environ. Res. Public Health 2021, 18, 6842. https:// doi.org/10.3390/ijerph18136842

Academic Editors: Igor Pravst, Mary R. L'Abbé, Bridget Kelly, Sophie Hieke, Katja Žmitek and Anita Kušar

Received: 27 April 2021

Accepted: 20 June 2021

Published: 25 June 2021

Publisher's Note: MDPI stays neutral with regard to jurisdictional claims in published maps and institutional affiliations.

Copyright: (c) 2021 by the authors. Licensee MDPI, Basel, Switzerland. This article is an open access article distributed under the terms and conditions of the Creative Commons Attribution (CC BY) license (https:// creativecommons.org/licenses/by/ $4.0 /)$.

\begin{abstract}
Background. Given the lack of data about the nutritional value and other determinants of the consumption of foods and drinks sold in vending machines in European universities and the relevance of this sector in Spain, it is necessary to obtain scientific data on this topic. The present study aimed to assess the availability, nutritional profile and processing level of food products from vending machines at a Spanish public university and to investigate differences in nutritional profile according to the cost and promotion. Methods. Cross-sectional descriptive study. Data from all products available (3894) were collected and analysed using the criteria of the Spanish Agency for Consumption, Food Safety and Nutrition and the United Kingdom nutrient profiling model. The items were also classified according to the degree of industrial processing through the NOVA system. Promotion was assessed, taking into account where products were displayed in vending machines. Results. The most common products were sweets (23.4\% of the total options), coffee $(20.3 \%)$ and salty snacks (11.7\%). According to the combination of the two criteria used to assess nutritional profile, $48.6 \%$ of the products were classified as with low nutritional quality (LNQ). In addition, $73.8 \%$ of the items were categorised as "ultra-processed". Foods ( $\beta=0.31,95 \%$ CI $0.24,0.39$, $p<0.001)$ and hot drinks ( $\beta=0.46,95 \%$ CI $0.39,0.52, p<0.001)$ with high nutritional quality (HNQ) were more likely to have higher prices than alternatives with LNQ. Both foods and cold drinks that support healthy dietary recommendations were promoted to a lesser extent than those with LNQ $(p<0.001)$. Conclusion. Almost half of the products were of LNQ and three-quarters had a high level of processing. Moreover, foods and cold drinks with LNQ were less expensive and more often promoted than alternatives with HNQ.
\end{abstract}

Keywords: food environment; vending machines; snacks; drinks; nutrient profile model; university; public health

\section{Introduction}

Over the last decades, obesity rates have increased [1]. Precursors for obesity, such as poor nutrition and physical inactivity, that are related to physical and social environments are increasingly recognised [2]. Until recently, individuals were viewed as being solely responsible for their lifestyle choices with little regard given to the environments within which the choices were made. Both the social-ecological framework and the reciprocal determinism construct from social cognitive theory posit that environments and behaviours affect each other concurrently [3]. Environments that encourage choices that support healthy dietary recommendations could make it easier for individuals to achieve and/or maintain health goals, such as healthy weight status and an adequate micronutrient status, compared with environments that fail to support the choice of this type of food [4]. 
Studies of food environments to date have shown that many primary, secondary and post-secondary schools have an accessible and ubiquitous supply of foods and drinks that are not nutrient-dense and do not support healthy dietary recommendations [5-8]. Food and drink availability and accessibility constitute key elements for dietary behaviours, as they determine what can be eaten at a certain time and place [9]. Vending machines have been identified as sources of products with high energy value, high sugar and saturated fat, and low nutritional value [10-12]. Often, these products are the main source of food and drinks available in public spaces such as universities, where they are widespread across campuses and are particularly attractive to time-stressed, hungry students and workers of higher education institutions [7].

In vending machine audit studies from universities in Australia, the UK, and the USA, the proportions of items of low nutritional quality (LNQ) available ranged from $85 \%$ to $100 \%$ for foods and from $49 \%$ to $86 \%$ for drinks $[6,7,13,14]$. This fact is contrary to what is expected in the post-secondary education environment, which should promote healthy lifestyles that can set the stage for lifelong choices affecting health [15]. Tertiary institutions offer a convenient setting to target young adults in public health efforts, with 17.5 million students attending higher education institutions in 2018 in the European Union [16] and more than $40 \%$ of 30 - to 34-year-olds having completed tertiary education [17].

Beyond taste and food preferences, other factors that may influence consumer purchasing from vending machines include pricing and promotion $[18,19]$. The price of vending machine products strongly influences consumer purchasing patterns, and when options with high nutritional quality (HNQ) are offered at a reduced cost, the sales of options with HNQ increase $[10,20]$. Consumers of products sold are also influenced by product logos, labels, and advertisement brand marketing [21,22]. To date, this last factor has been analysed through data related to any promotions on, inside or around the machine and the location of the machine $[7,13]$.

Spain is one of the European leaders in vending machine use, with one machine for every 80 inhabitants [23] (the European average is of one for every 180 inhabitants [24]). In 2015, Spain dominated the European vending landscape along with five other countries: France, Germany, Italy, Netherlands and the UK [24]. Given the lack of data about the nutritional value and other determinants of the consumption of foods and drinks sold in vending machines in European universities $[6,25]$ and the relevance of this sector in Spain, it is necessary to obtain scientific data on this topic. This work aimed to assess food products offered in vending machines at the University of the Basque Country (UPV/EHU) (in northern Spain), paying special attention to their nutritional profile and processing level, and to investigate differences in nutritional profile according to cost and promotion. This last factor (where items are displayed in the machine) is a new tool for the analysis of product promotion; it has not been previously used in vending machine assessment studies.

\section{Materials and Methods}

A cross-sectional study was carried out during the 2016/17 and 2017/18 academic years, specifically between February and November 2017. Vending machines of UPV/EHU in that period were managed by two contracted companies. During this period, the companies that were awarded the contracts did not change, and neither did the number of machines, nor the products offered, nor the price of the products. Data were recorded for all the vending machines of the three campuses of UPV/EHU, except for machines that, due to their location, are not usually accessible to undergraduate students ( $n=24$ machines) since they are in buildings earmarked for research.

\subsection{Data Collection}

Data related to the food and drinks offered at these points-of-sale were collected through a form developed for this study before data registration. This form included the following information: the number and type of machines and of food and drinks, building type (academic buildings, library, recreation facilities and other vending machines 
located in cafeterias or canteens, as described by other authors) [13], building floor, product description, location in the machine and portion price. The information collected regarding the product was as follows: flavour or ingredient variations, such as barbecue or plain potato chips, brand, portion weight, ingredients and nutrition labelling information (when it was available). The foods and drinks identified were assigned in one of the food/drink categories, according to the document on vending machines in schools developed by the Spanish Agency for Consumption, Food Safety and Nutrition (AECOSAN) and the Global Food Monitoring Group food categorisation system [26,27]. The price per portion was converted to euros for every $1 \mathrm{~kg} / \mathrm{L}(€ / \mathrm{kg}$ or $€ / \mathrm{L})$ to make comparisons between products.

Cold and hot foods were grouped into the same category because the number of hot foods was small ( $0.9 \%$ of total foods). Duplicate items were also noted, as other authors previously did [5], to have complete information about the food offerings. In addition, digital photographs were taken of all machines, specifically a photograph of the entire machine, with an approximate distance of $2 \mathrm{~m}$ from the machine, and a photograph for every two rows, with an approximate distance of $1 \mathrm{~m}$.

\subsection{Food Product Assessment: Nutritional Profile and Processing Level}

Information about food and drink nutritional composition was obtained from different sources, as follows (according to the order of preference): nutrition labelling, manufacturer's website and/or the DIAL program 2.12, a food composition database developed for the Spanish population [28]. When the nutritional information required for this study was not available, these data were estimated from the ingredient list and the amount for each of them, using the DIAL program 2.12. The DIAL program was completed with the food composition tables of Mataix et al., (2009) whenever necessary [29]. For each product, the energy content and the following nutrients were estimated: proteins, sugars, dietary fibre, total fats, trans fatty acids (TFAs), saturated fatty acids (SFAs) and sodium content. These data were calculated per $100 \mathrm{~g}$ of product and per portion. In those products in which TFA data were not available in the nutrition labelling, nor on the manufacturer's website or in the DIAL program, they were estimated using the report "Content of Trans Fatty Acids in Foods in Spain, 2015" (Agencia Española de Seguridad Alimentaria y Nutrición-AECOSAN) [30], and the food composition database of the USDA (United States Department of Agriculture) [31].

To indicate the nutritional quality of each food or drink item, the following nutrient profiling models (NPMs) were used: those proposed by the AECOSAN [26] and the United Kingdom (UK) NPM [29]. The former criteria are those designed for the food supply present in vending machines, canteens and kiosks in education centres. AECOSAN criteria have six components: energy, total fat, SFAs, TFAs, sugar and salt. These criteria sets the following limits per $100 \mathrm{~g} / \mathrm{mL}$ of product: in foods $\leq 400 \mathrm{kcal}, \leq 15.6 \mathrm{~g}$ total fat, $\leq 4.4 \mathrm{~g}$ SFA, $\leq 1 \mathrm{~g}$ TFA, $\leq 30 \mathrm{~g}$ sugar and $\leq 1 \mathrm{~g}$ salt; and in drinks, $\leq 100 \mathrm{kcal}, \leq 3.9 \mathrm{~g}$ total fat, $\leq 1.1 \mathrm{~g}$ SFA, $\leq 0.25 \mathrm{~g}$ TFA,$\leq 7.5 \mathrm{~g}$ sugar and $\leq 0.25 \mathrm{~g}$ salt. Products that were over at least one of the cut-offs were considered of LNQ. These criteria focus on energy density and nutrients that have the potential to negatively impact on health or "at risk" nutrients, which can be a limitation when analysing the nutrient profiling. For this reason, we also used the United Kingdom NPM, which was developed by the UK Food Standards Agency [32]. This instrument is one of the most frequently validated models [33].

In addition to the "at risk" nutrients, the UK NPM also includes foods and nutrients considered to have a beneficial effect on health (i.e., fruit, vegetables, nuts, protein and fibre). The UK NPM uses a simple scoring system wherein points are allocated on the basis of the nutrient content of $100 \mathrm{~g}$ of food or drink. To do this, the nutrient content of each food and drink was assessed against a set of published criteria to determine whether it contains certain nutrients above or below particular thresholds. This model has seven components: energy, SFA, sugar, sodium, "fruit, vegetables and nuts", fibre and protein; and provides a single score for any given food/drink product, based on calculating the number of points for "negative" nutrients that can be offset by points for 
"positive" nutrients. Points are awarded for energy, SFA, sugar and sodium ("A" nutrients) and fruit, vegetable and nut content, fibre and protein (" $\mathrm{C}$ " foods and nutrients). The amounts of these components were determined from the food/drink labelling (ingredient list, proportion of the ingredients listed on the label that have the highest percentages and nutrition labelling), manufacturer's website and/or the dietary assessment that was carried out with the food composition database above-mentioned. The score for " $\mathrm{C}$ " foods and nutrients is subtracted from the " $\mathrm{A}$ " nutrients score to give a final score. If the score is $<4$ for foods or $<1$ for drinks, the product is classified as HNQ. When scores exceed these limits, however, the product is classified as LNQ.

Finally, the resulting categories after applying the two criteria mentioned above, AECOSAN and the UK Nutrient Profiling Model, were combined as follows: if a product had been classified as LNQ according to both classifications, it was considered LNQ. The rest of the products were categorised as NHQ. This criterion was agreed as being more rigorous than the one that would consider as LNQ those products that were classified as such according to one or both classification systems.

Additionally, the food or drink items were classified using the NOVA system [34], which categorises foods according to their nature, purpose and degree of industrial processing. This system distinguishes between the following groups: (i) unprocessed or minimally processed foods, (ii) processed culinary ingredients, (iii) processed foods and (iv) ultra-processed products. This last group, ultra-processed foods, are formulations made mostly or entirely from substances derived from foods (e.g., casein, lactose, whey, gluten, hydrogenated oils and maltodextrin, among others) and additives (e.g., colour stabilizers, flavour enhancers, non-sugar sweeteners and emulsifiers, among others), with little if any intact unprocessed or minimally processed. In the present study, the category "processed culinary ingredients" was not assessed because this type of product was not offered in the vending machines studied. However, these types of products were part of ready-to-eat foods such as salads with dressing that were classified as processed foods.

\subsection{Location in the Vending Machine: Promotion of Products}

The promotion of food and drinks was assessed through their location in the vending machines, based on the information recorded in the abovementioned photographs. It should be noted that none of the vending machines analysed had advertisements inside, around or on the vending machine fronts. Merchandising criteria were used to classify the products according to their location in the machine: ground level (at a height of less than $80 \mathrm{~cm}$ from the ground); hand level (from $80 \mathrm{~cm}$ to $120 \mathrm{~cm}$ ); eye level (from $120 \mathrm{~cm}$ to $170 \mathrm{~cm}$ ); and head level (more than $170 \mathrm{~cm}$ ) [35]. To facilitate the data analysis, this classification was regrouped as follows: if the product was located at a height between $80 \mathrm{~cm}$ and $170 \mathrm{~cm}$, it was considered to be promoted; in contrast, at heights above $170 \mathrm{~cm}$ or under $80 \mathrm{~cm}$, the product was considered to be not promoted. Promotion was not evaluated for those products that were not directly visible to consumers (all hot drinks and some cold drinks), that is, those from vending machines that were either digital or non-transparent. In all these cases, the product selection panels, in which the list of products offered is displayed, were located at the level of the hands or eyes.

\subsection{Quality Management}

All data were collected by a single researcher (N.M.-P.) and reviewed by another researcher (M.A.-I.). We used unique vending machine identification numbers that were attached to each recording sheet. To check for quality data and derived indices (NPMs and level of processing), subsamples of machines and products were repeatedly examined. The data set was made available for analysis on a protected central data server. Access to the data is restricted to authorised members of the study. 


\subsection{Statistical Analysis}

We hypothesised that more than half of the products offered are of LNQ, from a nutritional point of view, and have a high level of processing; foods with HNQ are more expensive, while foods with LNQ are less expensive and are displayed in places that favour their consumption. The data were analysed using SPSS for Windows (version 24.0, SPSS Inc., Chicago, IL, USA). The results are expressed as the mean (standard deviation, $\mathrm{SD}$ ) and percentages. The distribution of values was examined for normality by the Kolmogorov-Smirnov-Lilliefors test. Non-parametric tests were performed for data that were non-normally distributed. The kappa coefficient was calculated to investigate the degree of agreement between the two NPMs (AECOSAN and UK NPM). The kappa results were interpreted as follows: values $\leq 0$ no agreement, $0.1-0.20$ none to slight, $0.21-0.40$ fair, 0.41-0.60 moderate, $0.61-0.80$ substantial and $0.81-1.00$ almost perfect [36].

The chi-square test was used to compare the nutritional profiles, processing levels, product promotion and price, according to the type of food (solid food, cold drink and hot drink). The cost differences, taking into account the product's nutritional profile, were determined by Mann-Whitney U test. Simple linear and binary logistic regression models were conducted to assess the associations of price (dependant variable, continuous) and promotion (dependant variable, categorical), respectively, with the nutritional profiles of products offered (independent variable resulting from the two criteria mentioned above, AECOSAN and the UK NPM, and the combination of both). Separate models were fit for each product category (hot and cold foods, cold drinks, hot drinks). All tests were two-sided, and $p$-values less than 0.05 were considered statistically significant.

\section{Results}

A total of 202 vending machines were studied across the three campuses (35 at the Álava/Araba campus, 102 at the Bizkaia campus, and 65 at the Gipuzkoa campus) of UPV/EHU. According to data provided by the Rector's Office of the UPV/EHU, 42,598 students and 7482 workers were potential consumers of products available at the university's vending machines; thus, there was one machine for every 248 members of the university community. Number of foods and drinks studied by category and subcategories are presented in Table 1.

Table 1. Numbers of food and drink products by category and subcategory.

\begin{tabular}{|c|c|c|c|}
\hline Product & Category & Subcategory & $n(\%)$ \\
\hline \multirow{22}{*}{ Cold/hot foods } & \multirow{6}{*}{ Sweet snacks } & Bakery and pastry products & $207(12.0)$ \\
\hline & & Biscuits & $191(11.1)$ \\
\hline & & Cereal bars & $96(5.6)$ \\
\hline & & Chocolate & $78(4.5)$ \\
\hline & & Chocolate bars & $293(17.0)$ \\
\hline & & Jellybeans & $48(2.8)$ \\
\hline & \multirow{6}{*}{ Salty snacks } & Bakery products (for example, breadsticks) & $104(6.0)$ \\
\hline & & $\begin{array}{c}\text { Other bakery products (for example, } \\
\text { empanadillas) }\end{array}$ & $2(0.1)$ \\
\hline & & Chips & $109(6.3)$ \\
\hline & & Crackers & $14(0.8)$ \\
\hline & & Fried corn & 27 (1.6) \\
\hline & & Extruded snacks (for example, “Doritos") & $195(11.3)$ \\
\hline & \multirow[b]{2}{*}{ Salads } & Rice/corn cakes & $5(0.3)$ \\
\hline & & Salads & $1(0.1)$ \\
\hline & \multirow[t]{3}{*}{ Sandwiches } & Cold sandwiches & $168(9.8)$ \\
\hline & & $\begin{array}{l}\text { Hot sandwiches } \\
\text { Fried nuts with salt }\end{array}$ & $16(0.9)$ \\
\hline & & $\begin{array}{l}\text { Fried nuts with salt } \\
\end{array}$ & $68(3.9)$ \\
\hline & \multirow[t]{2}{*}{ Nuts } & Natural or toasted nuts without salt & $1(0.1)$ \\
\hline & & $\begin{array}{c}\text { Natural or toasted nuts with salt } \\
\text { Fresh fruit }\end{array}$ & $10(0.6)$ \\
\hline & Fresh fruit & $\begin{array}{c}\text { Fresh fruit } \\
\text { Candies with added sugars }\end{array}$ & $2(0.1)$ \\
\hline & \multirow[t]{3}{*}{ Other food } & $\begin{array}{l}\text { Candies with added sugars } \\
\text { Candies with sweeteners }\end{array}$ & $1(0.1)$ \\
\hline & & Chewing gum with sweeteners & $82(4.8)$ \\
\hline Total & & & 1723 \\
\hline
\end{tabular}


Table 1. Cont.

\begin{tabular}{|c|c|c|c|}
\hline Product & Category & Subcategory & $n(\%)$ \\
\hline Cold drinks & $\begin{array}{c}\text { Bottled water } \\
\text { Carbonated drinks } \\
\text { Non-carbonated drinks } \\
\text { Beer } \\
\text { Dairy cold drinks } \\
\text { Fruit juice }\end{array}$ & $\begin{array}{c}\text { Bottled water } \\
\text { Carbonated drinks with sugar and sweeteners } \\
\text { Carbonated drinks with sweeteners } \\
\text { Sugar sweetened carbonated drinks } \\
\text { Carbonated drinks with juice } \\
\text { Soda } \\
\text { Isotonic drinks } \\
\text { Non-carbonated drinks with sugar and } \\
\text { sweeteners } \\
\text { Soft drinks with juice } \\
\text { Alcohol-free beer } \\
\text { Beer with alcohol } \\
\text { Coffee } \\
\text { Chocolate } \\
\text { Concentrated juices } \\
\text { Juice with milk } \\
\text { Nectars }\end{array}$ & $\begin{array}{l}341(30.1) \\
6(0.5) \\
148(13.1) \\
232(20.5) \\
39(3.5) \\
1(0.1) \\
111(9.8) \\
28(2.5) \\
56(4.9) \\
1(0.1) \\
1(0.1) \\
2(0.2) \\
5(0.4) \\
5(0.4) \\
1(0.1) \\
120(10.6) \\
36(3.2) \\
1133\end{array}$ \\
\hline Hot drinks & $\begin{array}{c}\text { Infusions } \\
\text { Other hot drinks }\end{array}$ & $\begin{array}{c}\text { Milk } \\
\text { Small coffee } \\
\text { Large coffee } \\
\text { Coffee with a little milk } \\
\text { Coffee with milk } \\
\text { Bonbon coffee } \\
\text { Irish coffee } \\
\text { Hazelnut coffee } \\
\text { Cappuccino } \\
\text { Hazelnut cappuccino } \\
\text { Italian cappuccino } \\
\text { Mocha } \\
\text { Milk with a little coffee } \\
\text { Small decaffeinated coffee } \\
\text { Large decaffeinated coffee } \\
\text { Decaffeinated coffee with a little milk } \\
\text { Decaffeinated coffee with milk } \\
\text { Decaffeinated cappuccino } \\
\text { Decaffeinated hazelnut cappuccino } \\
\text { Milk with a little decaffeinated coffee } \\
\text { Hot chocolate } \\
\text { Hot chocolate with milk } \\
\text { Viennese chocolate } \\
\text { White chocolate } \\
\text { Tea } \\
\text { Tea with lemon } \\
\text { Hot water } \\
\text { Broths }\end{array}$ & $\begin{array}{l}64(6.2) \\
72(6.9) \\
73(7.0) \\
73(7.0) \\
74(7.1) \\
1(0.1) \\
1(0.1) \\
29(2.8) \\
73(7.0) \\
8(0.8) \\
31(3.0) \\
32(3.1) \\
55(5.3) \\
64(6.1) \\
28(2.7) \\
66(6.4) \\
66(6.4) \\
29(2.8) \\
3(0.3) \\
11(1.1) \\
68(6.5) \\
27(2.6) \\
31(3.0) \\
1(0.1) \\
2(0.2) \\
46(4.4) \\
1(0.1) \\
9(0.9) \\
1038\end{array}$ \\
\hline
\end{tabular}

Table 2 presents the number of vending machines according to campus and building type, the type of vending machine, and the number of products categorised by type. Overall, the percentage of drink machines (70.3\%; cold drinks $37.6 \%$ and hot drinks $32.7 \%$ ) was higher than those of only food and those with mixed offerings $(p<0.001)$ (Table 2$)$, as was the percentage of drinks compared to that of food items $(55.8 \%$ vs. $44.2 \%, p<0.001$; percentages calculated from the data presented in Table 1). Taking into account the building type, academic buildings had the largest number of vending machines. 
Table 2. Types of vending machines and products sold at the University of the Basque Country (Spain) by campus.

\begin{tabular}{|c|c|c|c|c|c|c|c|c|c|c|c|c|}
\hline \multirow{3}{*}{ Campus } & \multirow{3}{*}{$\begin{array}{l}\text { Building } \\
\text { Types }\end{array}$} & \multicolumn{5}{|c|}{ Type of Food/Drink Vending Machine } & \multicolumn{6}{|c|}{ Type of Product } \\
\hline & & \multirow{2}{*}{$\begin{array}{c}\text { Total, } n \\
\quad(\%)\end{array}$} & HF & $\mathrm{CD}$ & HD & $\mathbf{M}$ & \multirow{2}{*}{$\begin{array}{c}\text { Total, } n \\
(\%)\end{array}$} & HF & $\mathrm{CD}$ & HD & $\mathrm{CF}$ & \multirow{2}{*}{$p^{\mathrm{a}}$} \\
\hline & & & \multicolumn{4}{|c|}{$\%$} & & \multicolumn{4}{|c|}{$\%$} & \\
\hline \multirow{4}{*}{$\mathrm{A}$} & $\begin{array}{l}\text { Academic } \\
\text { buildings }\end{array}$ & $24(68.6)$ & - & 61.5 & 72.7 & 72.7 & $537(70.8)$ & - & 64.8 & 73.9 & 73.1 & \\
\hline & Library & $7(20.0)$ & - & 23.1 & 18.2 & 18.2 & $157(20.7)$ & - & 21.5 & 18.5 & 21.3 & \\
\hline & Other $b$ & $4(11.4)$ & - & 15.4 & 9.1 & 9.1 & $65(8.6)$ & - & 13.7 & 7.6 & 5.6 & \\
\hline & Total & $35(100.0)$ & - & 37.1 & 31.4 & 31.4 & 759 & - & 30.7 & 24.2 & 45.1 & 0.010 \\
\hline \multirow{5}{*}{ B } & $\begin{array}{l}\text { Academic } \\
\text { buildings }\end{array}$ & $94(92.2)$ & 100.0 & 87.8 & 93.8 & 96.2 & 1756 (91.1) & 100.0 & 82.5 & 93.5 & 96.3 & \\
\hline & Library & $1(1.0)$ & - & - & 3.1 & - & $16(0.8)$ & - & - & 3.3 & - & \\
\hline & $\begin{array}{l}\text { Recreation } \\
\text { facilities }\end{array}$ & $2(2.0)$ & - & 2.4 & - & 3.8 & $44(2.3)$ & - & 2.5 & - & 3.8 & \\
\hline & Other ${ }^{b}$ & $5(4.9)$ & - & 9.8 & 3.1 & - & $112(5.8)$ & - & 15.3 & 3.3 & - & \\
\hline & Total & $102(100.0)$ & 2.9 & 39.8 & 25.2 & 31.1 & 1928 & 0.4 & 32.6 & 25.5 & 41.5 & 0.004 \\
\hline \multirow{4}{*}{ G } & $\begin{array}{l}\text { Academic } \\
\text { buildings }\end{array}$ & 49 (75.1) & - & 72.7 & 82.6 & 70.0 & 919 (76.1) & - & 75.7 & 82.3 & 72.4 & \\
\hline & Library & $5(7.7)$ & - & 4.5 & 8.7 & 10.0 & $104(8.6)$ & - & 5.5 & 8.8 & 9.9 & \\
\hline & Other $\mathrm{b}$ & $11(16.9)$ & - & 22.7 & 8.7 & 20.0 & $184(15.2)$ & - & 18.8 & 8.8 & 17.6 & \\
\hline & Total & 65 (100.0) & - & 30.8 & 30.8 & 38.5 & 1207 & - & 22.5 & 30.0 & 47.5 & $<0.001$ \\
\hline \multirow{5}{*}{ Total } & $\begin{array}{l}\text { Academic } \\
\text { buildings }\end{array}$ & 167 (82.7) & 100.0 & 78.9 & 86.4 & 82.5 & $3212(82.5)$ & 100.0 & 77.2 & 86.1 & 83.7 & \\
\hline & Library & $13(6.4)$ & - & 5.3 & 7.6 & 7.0 & 277 (7.1) & - & 5.7 & 7.9 & 7.6 & \\
\hline & $\begin{array}{l}\text { Recreation } \\
\text { facilities }\end{array}$ & $2(1.0)$ & - & 1.3 & - & 1.8 & 44 (1.1) & - & 1.2 & - & 1.7 & \\
\hline & Other $\mathrm{b}$ & $20(9.9)$ & - & 14.5 & 6.1 & 8.8 & $361(9.3)$ & - & 15.8 & 6.0 & 7.0 & \\
\hline & Total & $202(100.0)$ & 1.5 & 37.6 & 32.7 & 28.2 & 3894 & 0.2 & 29.1 & 26.7 & 44.0 & $<0.001$ \\
\hline
\end{tabular}

Abbreviations: HF, hot foods; CD, cold drinks; M, mixed hot foods/drink; HD, hot drinks; CF, cold foods; A, Araba/Álava; B, Bizkaia; G, Gipuzkoa. Note: ${ }^{a}$ Chi-square was used to assess differences in the frequency distribution of types of products by Campus. Significant $p$-values are highlighted in bold; ${ }^{b}$ Other: vending machines in cafeterias or canteens in several buildings.

A total of 3894 foods and drinks were surveyed in 40 buildings on three campuses. According to the NOVA system, most of the products offered were categorised as "ultraprocessed", specifically $73.8 \%$ of the total $(99.7 \%$ of the cold and hot foods, $69.8 \%$ of the cold drinks and $35.3 \%$ of the hot drinks, $p<0.001$ ) (Table 3). As shown in Table 4 , the most common snack options were sweets (i.e., chocolate bars, biscuits) $(23.4 \%$ of the total options), followed by coffee $(20.3 \%)$ and salty snacks $(11.7 \%)$. The most common product among cold and hot foods was sweet snacks (53\% of the hot and cold foods), among cold drinks was bottled water ( $30.1 \%$ of the cold drinks), and among hot drinks was coffee ( $76 \%$ of the hot drinks). According to their nutritional profiles, more than half of the foods and drinks did not meet the AECOSAN criteria (53.9\%) or the UK NPM criteria (51.5\%). 
Table 3. Processing levels of products offered in food and drink vending machines at the University of the Basque Country (Spain).

\begin{tabular}{|c|c|c|c|}
\hline \multirow{2}{*}{ Type of Product $(n)$} & \multicolumn{3}{|c|}{ NOVA Classification System ${ }^{a}, \%$} \\
\hline & Not Processed $^{b}$ & Processed & Ultra-Processed \\
\hline \multicolumn{4}{|l|}{ Cold/hot foods } \\
\hline Fresh fruit (2) & 100 & - & - \\
\hline Nuts (79) & 1.3 & 1.3 & 97.5 \\
\hline Salty snacks (456) & - & - & 100.0 \\
\hline Salads (1) & - & 100.0 & \\
\hline \multicolumn{4}{|l|}{ Sandwiches } \\
\hline cold sandwiches (168) & - & - & 100.0 \\
\hline hot sandwiches (16) & - & - & 100.0 \\
\hline \multicolumn{4}{|l|}{ Sweets and chewing gum } \\
\hline with added sugars (5) & - & - & 100.0 \\
\hline with sweeteners (83) & - & - & 100.0 \\
\hline Sweet snacks (913) & - & - & 100.0 \\
\hline Total (1723) & 0.2 & 0.1 & 99.7 \\
\hline \multicolumn{4}{|l|}{ Cold drinks } \\
\hline Beer (3) & - & - & 100.0 \\
\hline Bottled water (341) & 100 & - & - \\
\hline \multicolumn{4}{|l|}{ Carbonated drinks } \\
\hline $\begin{array}{c}\text { without sugar or sweeteners } \\
\text { (1) }\end{array}$ & & 100.0 & \\
\hline with added sugars (234) & - & - & 100.0 \\
\hline with sweeteners (148) & - & & 100.0 \\
\hline $\begin{array}{l}\text { with added sugars and } \\
\text { sweeteners (43) }\end{array}$ & - & - & 100.0 \\
\hline Dairy products (10) & - & - & 100.0 \\
\hline Fruit juice (157) & - & - & 100.0 \\
\hline \multicolumn{4}{|l|}{ Non-carbonated drinks } \\
\hline with added sugars (19) & - & - & 100.0 \\
\hline with added sugar and & - & - & 100.0 \\
\hline $\begin{array}{l}\text { sweeteners }(1 / 7) \\
\text { Total (1133) }\end{array}$ & 30.1 & 0.1 & 69.8 \\
\hline \multicolumn{4}{|l|}{ Hot drinks } \\
\hline Broths (9) & _ & - & 100.0 \\
\hline Coffee (789) & 71.0 & - & 29.0 \\
\hline Hot chocolate (127) & - & - & 100.0 \\
\hline Hot water (1) & 100.0 & - & - \\
\hline Infusions (48) & 100.0 & - & - \\
\hline Milk (64) & 100.0 & - & - \\
\hline Total (1038) & 64.7 & - & 35.3 \\
\hline Total (3894) & 26.1 & 0.1 & 73.8 \\
\hline
\end{tabular}

Note: ${ }^{\text {a }}$ Monteiro et al., $2016 ;^{\text {b }}$ Not processed or minimally processed.

Table 4. Nutritional profiles of products offered in vending machines at the University of the Basque Country (Spain).

\begin{tabular}{|c|c|c|c|c|c|c|c|c|c|c|c|}
\hline \multirow{3}{*}{ Type of Product } & \multicolumn{10}{|c|}{ Percentage Not Meeting Criteria } & \multirow{3}{*}{$\begin{array}{l}\text { AECOSAN } \\
+ \text { UK NPM } \\
\text { a,c, } \%\end{array}$} \\
\hline & $(0)$ & \multicolumn{7}{|c|}{ AECOSAN Criteria ${ }^{a, b}, \%$} & \multirow{2}{*}{$\begin{array}{c}\text { UK NPM } \\
\text { Criteria } \\
\text { b,c }, \% \\
\end{array}$} & \multirow{2}{*}{$p^{\mathrm{d}}$} & \\
\hline & $n(\%)$ & Energy & Total Fat & SFA & TFA & Sugars & Salt & Total & & & \\
\hline \multicolumn{12}{|l|}{ Cold/hot foods } \\
\hline Fresh fruit & $2(0.1)$ & - & - & - & - & - & - & - & - & - & - \\
\hline Nuts & $79(4.6)$ & 96.2 & - & 1.3 & 55.7 & 1.3 & 88.6 & 98.7 & 55.7 & 0.443 & 55.7 \\
\hline Salty snacks & $456(26.5)$ & 97.4 & 77.6 & 48.2 & 87.7 & 1.3 & 92.3 & 100.0 & 87.7 & - & 87.7 \\
\hline Salads & $1(0.1)$ & & & & & - & & & & & \\
\hline Cold sandwiches & $168(9.8)$ & 2.4 & 13.1 & 3.0 & 52.0 & - & 94.6 & 94.6 & 50.6 & 0.002 & 52.0 \\
\hline Hot sandwiches & $16(0.9)$ & 50.0 & 62.5 & 50.0 & 72.7 & - & 81.3 & 100.0 & 62.5 & - & 72.7 \\
\hline \multicolumn{12}{|l|}{$\begin{array}{l}\text { Sweets and chewing } \\
\text { gum }\end{array}$} \\
\hline with added sugars & $5(0.3)$ & 40.0 & - & - & 100.0 & 100.0 & - & 100.0 & 100.0 & - & 100.0 \\
\hline with sweeteners & $83(4.8)$ & - & - & - & - & - & - & - & - & - & - \\
\hline Sweet snacks & $913(53.0)$ & 88.5 & 88.9 & 91.2 & 93.8 & 75.0 & 8.7 & 97.8 & 95.8 & 0.577 & 93.8 \\
\hline Total ${ }^{\mathrm{e}}$ & 1723 & 77.9 & 69.5 & 61.9 & 81.4 & 40.5 & 43.1 & 93.3 & 82.5 & $<0.001$ & 81.4 \\
\hline
\end{tabular}


Table 4. Cont.

\begin{tabular}{|c|c|c|c|c|c|c|c|c|c|c|c|}
\hline \multirow{3}{*}{ Type of Product } & \multirow{3}{*}{$n(\%)$} & \multicolumn{7}{|c|}{ Percentage Not Meeting Criteria } & \multirow{3}{*}{$\begin{array}{c}\text { UK NPM } \\
\text { Criteria } \\
b, c, \%\end{array}$} & \multirow{3}{*}{$p^{\mathrm{d}}$} & \multirow{3}{*}{ 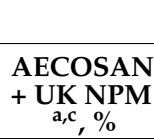 } \\
\hline & & \multicolumn{7}{|c|}{ AECOSAN Criteria ${ }^{a, b}, \%$} & & & \\
\hline & & Energy & Total Fat & SFA & TFA & Sugars & Salt & Total & & & \\
\hline \multicolumn{12}{|l|}{ Cold drinks } \\
\hline Beer & $3(0.3)$ & - & - & - & - & - & - & - & 33.3 & - & - \\
\hline Bottled water & $341(30.1)$ & - & - & - & - & - & - & - & - & - & - \\
\hline \multicolumn{12}{|l|}{ Carbonated drinks } \\
\hline $\begin{array}{l}\text { without sugar or } \\
\text { sweeteners }\end{array}$ & $1(0.2)$ & - & - & - & - & - & - & - & - & - & - \\
\hline with added sugars & $234(20.6)$ & - & - & - & 89.7 & 89.7 & - & 89.7 & 89.7 & - & 89.7 \\
\hline with sweeteners & $148(13.1)$ & - & - & - & - & - & - & - & - & - & - \\
\hline $\begin{array}{l}\text { with added sugar } \\
\text { and sweeteners }\end{array}$ & $43(3.8)$ & - & - & - & 86.0 & 86.0 & - & 86.0 & 88.4 & $<0.001$ & 86.0 \\
\hline Dairy products & $10(0.8)$ & - & - & - & 100.0 & 100.0 & - & 100.0 & 100.0 & - & 100.0 \\
\hline Fruit juice & $157(13.9)$ & - & - & - & 2.5 & 3.2 & - & 3.2 & 9.6 & $<0.001$ & 2.5 \\
\hline \multicolumn{12}{|l|}{$\begin{array}{l}\text { Non-carbonated } \\
\text { drinks }\end{array}$} \\
\hline \multirow{3}{*}{$\begin{array}{c}\text { with added sugars } \\
\text { with added sugar } \\
\text { and sweeteners } \\
\text { Total }^{\mathrm{e}}\end{array}$} & $19(1.7)$ & - & - & - & - & - & - & - & 94.7 & - & - \\
\hline & $177(15.6)$ & - & - & - & 47.5 & 47.5 & - & 47.5 & 80.2 & $<0.001$ & 47.5 \\
\hline & 1133 & - & - & - & 30.5 & 30.5 & - & 30.5 & 38.5 & $<0.001$ & 30.5 \\
\hline \multicolumn{12}{|l|}{ Hot drinks } \\
\hline Broths & $9(0.9)$ & - & - & - & 100.0 & - & 100.0 & 100.0 & 100.0 & - & 100.0 \\
\hline Coffee & $789(76.0)$ & - & - & - & 1.3 & 1.3 & - & 1.8 & 2.1 & $<0.001$ & 1.3 \\
\hline Hot chocolate & $127(12.2)$ & - & - & - & 100.0 & 100.0 & - & 100.0 & 100.0 & - & 100.0 \\
\hline Hot water & $1(0.1)$ & - & - & - & - & - & - & - & - & - & - \\
\hline Infusions & $48(4.6)$ & - & - & - & - & - & - & - & 2.1 & - & - \\
\hline Milk & $64(6.2)$ & - & - & - & - & - & - & - & - & - & - \\
\hline Total $^{\mathrm{e}}$ & 1038 & - & - & - & 14.1 & 13.2 & 0.9 & 14.1 & 14.5 & $<0.001$ & 14.1 \\
\hline Total & 3894 & 34.5 & 30.8 & 27.4 & 48.6 & 30.3 & 19.3 & 53.9 & 51.5 & $<0.001$ & 48.6 \\
\hline
\end{tabular}

Abbreviations: NPM, nutrient profiling model; SFA, saturated fat acids; TFA, trans fatty acids. Note: ${ }^{a}$ AECOSAN, $2010{ }^{b}{ }^{b}$ The same product may not meet more than one criterion, and therefore, the sum of the criteria does not result in the total percentage of products that do not fulfil AECOSAN criteria; ${ }^{\mathrm{C}}$ Department of Health of the UK, 2011; ${ }^{\mathrm{d}}$ Chi-square was used to assess differences between percentage not meeting the AECOSAN criteria and the UK NPM criteria. Significant $p$-values are highlighted in bold; and ${ }^{\mathrm{e}}$ the total rows present percentages with respect to the total of each type of product.

The combination of the two criteria mentioned above, the AECOSAN and the UK NPM, showed that $48.6 \%$ of the products were classified as LNQ. It should be noted that among the non-carbonated drinks with added sugars, all met the AECOSAN criteria, while $94.7 \%$ did not meet the UK NMP criteria. These differences in the results obtained from the two NPMs are related to discrepancies in constructs and scoring criteria. These products had an average of $5.6 \mathrm{~g}$ of sugars per $100 \mathrm{~mL}$ (minimum $4.0 \mathrm{~g}$ and maximum $6.6 \mathrm{~g}$ ). The sugar limit according to the AECOSAN criteria is $\leq 7.5 \mathrm{~g}$ in $100 \mathrm{~mL}$ drinks. Therefore, all these items met this and the rest of the AECOSAN criteria. Nevertheless, with the UK NMP, the scores for this "at risk" nutrient (sugar), as well as the one assigned to the foods and nutrients considered to have a beneficial effect on health, were low or null, so the results gave a high percentage of items classified as "with LNP".

Comparison of the results obtained from the two NPMs showed an almost perfect agreement between UK NPM and AECOSAN (Supplementary Table S1). The lowest level of agreement was obtained for cold/hot foods; specifically, no agreement was observed for nuts $(\kappa=0.032)$ and sweet snacks $(\kappa=0.006)$, and the agreement was none to slight for cold sandwiches $(\kappa=0.112)$. The percentage of products that did not meet the AECOSAN and the UK NPM criteria was higher for hot and cold foods, followed by cold drinks and finally hot drinks. Among hot and cold foods, those products that met the AECOSAN and/or the UK NPM criteria to a lesser extent were salty snacks, hot sandwiches and sweets and chewing gum with added sugars; among cold drinks, dairy products; and among hot drinks, broths and hot chocolate. The AECOSAN criteria that were most frequently unfulfilled were the energy, total fat and SFA quantity in foods and the sugar content in drinks.

Regarding the comparison between the NPMs and processing level classification, in general a moderate agreement was observed between the NOVA system and each of the NPMs, separately and also combined (Supplementary Table S2). The lowest level of 
agreement between NPMs and NOVA system was obtained for cold/hot foods. Table 5 shows the relationships between nutritional profile and the promotion and price of products offered in vending machines. The hot and cold foods with LNQ, especially salty and sweet snacks, and hot drinks with LNQ were less expensive than the healthy foods $(p<0.001)$, whereas among cold drinks the results were the reverse $(p<0.05)$. Specifically, the price of bottled water (mean, 0.8 ; SD, $0.4 € / \mathrm{L}$ ) was significantly lower than that of soft drinks (mean, 2.5; SD, $1.1 € / \mathrm{L})(p<0.001)$. Moreover, hot and cold foods with LNQ were promoted to a greater extent than healthy foods $(p<0.05)$. With respect to associations between product price and promotion, the promoted hot and cold foods were more expensive than those that were not promoted (mean, 18.6; SD, $11.6 € / \mathrm{kg}$ vs. $12.1 ; 6.8 € / \mathrm{kg} ; p<0.001$ ), while among cold drinks, the reverse was true (mean, $1.8 ; \mathrm{SD}, 1.2 € / \mathrm{L}$ vs. $2.6 ; 1.4 € / \mathrm{L} ; p<0.001$ ).

Table 5. Relationships between nutritional profile and the promotion and price of products offered in vending machines at the University of the Basque Country (Spain).

\begin{tabular}{|c|c|c|c|c|c|c|c|c|}
\hline \multirow[b]{2}{*}{ Type of Product ( $n$ ) } & \multicolumn{3}{|c|}{ Price, $€ / \mathrm{kg}$ or $\mathrm{L}$} & \multirow[b]{2}{*}{$p^{\mathrm{c}}$} & \multicolumn{3}{|c|}{ Promoted Products ${ }^{a}$} & \multirow[b]{2}{*}{$p^{\mathrm{c}}$} \\
\hline & $\begin{array}{c}\text { Total, } \\
\text { Mean (SD) }\end{array}$ & $\begin{array}{c}\text { PHNQ } \\
(n=1659) \\
\text { Mean (SD) }\end{array}$ & $\begin{array}{c}\text { PLNQ } \\
(n=1894) \\
\text { Mean (SD) }\end{array}$ & & $\underset{n}{\text { Total }} \mathrm{d}$ & $\begin{array}{c}\text { PHNQ } \\
(n=27), \\
\%\end{array}$ & $\begin{array}{c}\text { PLNQ } \\
(n=184) \\
\%\end{array}$ & \\
\hline \multicolumn{9}{|l|}{ Cold/hot foods } \\
\hline Fresh fruit (2) & $3.8(0.2)$ & $3.8(0.2)$ & - & - & - & - & - & - \\
\hline Nuts (79) & $12.6(4.5)$ & $12.5(6.4)$ & $12.7(2.3)$ & 0.513 & 69 & $28(40.6)$ & $41(59.4)$ & 0.099 \\
\hline Salty snacks (456) & $14.3(6.5)$ & $22.0(6.1)$ & $13.3(5.9)$ & $<0.001$ & 356 & $32(9.0)$ & $324(91.0)$ & $<0.001$ \\
\hline Salads (1) & $6.9(-)$ & $6.9(-)$ & - & - & - & - & - & - \\
\hline Cold sandwiches (168) & $7.3(2.0)$ & $6.7(2.1)$ & $10.3(2.5)$ & 0.003 & 36 & $18(50.0)$ & $18(50.0)$ & 0.936 \\
\hline Hot sandwiches (16) & $9.6(2.8)$ & $7.6(2.3)$ & $7.0(1.6)$ & 0.057 & 8 & - & $8(100.0)$ & 0.200 \\
\hline \multicolumn{9}{|l|}{ Sweets and chewing gum } \\
\hline with added sugars (5) & $26.3(0.0)$ & - & $26.3(0.0)$ & - & 3 & - & $3(100.0)$ & - \\
\hline with sweeteners (83) & $43.2(12.7)$ & $43.2(12.7)$ & - & - & 83 & $83(100.0)$ & - & - \\
\hline Sweet snacks (913) & $18.6(10.2)$ & $32.8(10.5)$ & $17.7(9.5)$ & $<0.001$ & 797 & $56(7.0)$ & $741(93.0)$ & 0.010 \\
\hline Total (1723) & $17.2(11.1)$ & $24.3(16.6)$ & $15.6(8.6)$ & $<0.001$ & 1352 & $217(16.0)$ & $\begin{array}{l}1135 \\
(84.0)\end{array}$ & $<0.001$ \\
\hline \multicolumn{9}{|l|}{ Cold drinks } \\
\hline Beer (3) & $3.3(0.4)$ & $3.3(0.4)$ & - & - & - & - & - & - \\
\hline Bottled water (341) & $0.8(0.4)$ & $0.8(0.4)$ & - & - & 58 & $58(100.0)$ & - & - \\
\hline \multicolumn{9}{|l|}{ Carbonated drinks } \\
\hline $\begin{array}{l}\text { without sugars or } \\
\text { sweeteners }(1)\end{array}$ & $3.0(-)$ & $3.0(-)$ & - & - & 1 & $1(100.0)$ & - & - \\
\hline with added sugars (234) & $2.6(1.5)$ & $1.3(0.6)$ & $2.8(1.6)$ & $<0.001$ & 35 & - & $35(100.0)$ & $<0.001$ \\
\hline with sweeteners (148) & $2.0(0.5)$ & $2.0(0.5)$ & - & - & 21 & $21(100.0)$ & - & - \\
\hline $\begin{array}{l}\text { with added sugar and } \\
\text { sweeteners (43) }\end{array}$ & $2.4(0.7)$ & $3.0(0.5)$ & $2.3(0.7)$ & 0.042 & 5 & $2(40.0)$ & $3(60.0)$ & 1.000 \\
\hline Dairy products (10) & $6.0(0.4)$ & - & $6.0(0.4)$ & - & 1 & - & $1(100.0)$ & - \\
\hline Fruit juice (157) & $2.5(0.6)$ & $2.5(0.6)$ & $3.5(1.1)$ & 0.041 & 8 & $6(75.0)$ & $2(25.0)$ & 0.013 \\
\hline \multicolumn{9}{|l|}{ Non-carbonated drinks } \\
\hline with added sugars (19) & $1.9(1.0)$ & $1.9(1.0)$ & - & - & 9 & $9(100.0)$ & - & - \\
\hline $\begin{array}{l}\text { with added sugar and } \\
\text { sweeteners (177) }\end{array}$ & $2.5(0.7)$ & $2.7(0.8)$ & $2.3(0.5)$ & 0.004 & 21 & $13(61.9)$ & $8(38.1)$ & 0.079 \\
\hline Total (1133) & $2.0(1.2)$ & $1.7(1.0)$ & $2.7(1.4)$ & $<0.001$ & 159 & $110(69.2)$ & $49(30.8)$ & $<0.001$ \\
\hline \multicolumn{9}{|l|}{ Hot drinks } \\
\hline Broths (9) & $3.6(0.5)$ & - & $3.6(0.5)$ & - & - & - & - & - \\
\hline Coffee (789) & $3.6(1.2)$ & $3.6(1.2)$ & $4.9(1.7)$ & 0.003 & - & - & - & - \\
\hline Hot chocolate (127) & $2.1(0.9)$ & - & $2.1(0.9)$ & - & - & - & - & - \\
\hline Hot water (1) & $1.0(-)$ & $1.0(-)$ & - & - & - & - & - & - \\
\hline Infusions (48) & $2.2(1.0)$ & $2.2(1.0)$ & - & - & - & - & - & - \\
\hline Milk (64) & $3.2(0.7)$ & $3.2(0.7)$ & - & - & - & - & - & - \\
\hline Total (1038) & $3.3(1.3)$ & $3.5(1.2)$ & $2.4(1.2)$ & $<0.001$ & - & - & - & - \\
\hline Total (3894) & $9.1(10.4)$ & $6.1(10.4)$ & $12.2(9.4)$ & $<0.001$ & 1511 & $327(21.6)$ & $\begin{array}{c}1184 \\
(78.4)\end{array}$ & $<0.001$ \\
\hline
\end{tabular}

Abbreviations: SD, standard deviation; PHNQ, products of high nutritional quality; PLNQ products with low quality. Note: ${ }^{\text {a }}$ If the product was located at a height between $80 \mathrm{~cm}$ and $170 \mathrm{~cm}$, it was considered to be promoted; ${ }^{\mathrm{b}}$ If a product had been classified as LNQ according to AECOSAN and UK nutrient profiling model criteria, it was considered with LNQ; ${ }^{c}$ Mann-Whitney U test was used to assess differences between PHNQ and PLNQ, significant $p$-values are highlighted in bold; ${ }^{d}$ Product promotion was not evaluated for those products that were not in view, because all the product selection panels were located at hand or eye level $(n=1677)$. 
Simple linear regression analyses showed that the product's price was associated with its nutritional profile. Hot and cold foods $(\beta=0.31,95 \%$ CI $0.24,0.39, p<0.001)$ and hot drinks that support healthy dietary recommendations ( $\beta=0.46,95 \%$ CI 0.39 , $0.52, p<0.001)$ were more likely to have higher prices than alternatives with LNQ (Supplementary Table S3). Among cold drinks, this association was inverse ( $\beta=-0.57$, $95 \%$ CI $-0.64,-0.50, p<0.001)$. Moreover, both cold/hot foods and cold drinks that support healthy dietary recommendations were promoted to a lesser extent than those with LNQ (cold/hot foods, OR $=0.50,95 \%$ CI 0.38, 0.65, $p<0.001$; cold drinks, OR $=0.45$, 95\% CI 0.29, 0.70, $p<0.001$ ) (Supplementary Table S4).

\section{Discussion}

The current study aimed to assess the nutritional profiles of foods and drinks sold in vending machines at a Spanish public university and to investigate differences in these profiles according to the cost and the product's location in the machine. The most common products for sale in vending machines were sweets (i.e., chocolate bars, biscuits), coffee and salty snacks, results that agree with other authors, both at the university level $[5,6]$ and in other settings $[37,38]$. Consistent with other studies conducted in university environments [5], it was found that almost half of the products offered for sale in vending machines at UPV/EHU were of LNQ (according to the combination of the two chosen criteria, the AECOSAN and the UK NPM criteria) and almost three-quarters had a high level of processing. Therefore, the initial hypothesis that more than half of the products offered are of LNQ and have a high level of processing was not completely confirmed. In any case, in the literature, the proportion of items sold with LNQ in vending machines available at campus universities was highly variable, probably because the criteria used were different $[5-7,13]$. It should also be noted that the processing level classification used in the present study showed a low level of agreement with the NPMs. This result is probably due to the fact that although ultra-processed foods usually are characterized by a high content of sugar, salt and/or fats, these contents do not always exceed the limits of the NPMs. In any case, ultra-processed foods had in general a worse nutrient profile than less-processed foods [39].

As other authors have pointed out, some of the potential reasons for filling vending machines with food with LNQ are the shelf life of the item and financial considerations [40]. Packaged snack products such as sweets and crisps often have a long shelf life and may not require refrigeration. However, an increasing number of vending companies are developing strategies to market vending machine products with HNQ that do not need to be refrigerated, and there are increasing numbers of refrigerated food-vending machines that can contain foods with HNQ that may be perishable [41,42]. Regarding financial considerations, marketing new products with HNQ may also be an effective way to promote sales and reduce any potential revenue loss $[40,43,44]$.

In the present study, the analysis of nutritional profile by the type of product showed that those that met the recommendations the least were hot and cold foods (especially salty snacks, hot sandwiches and sweets and chewing gum with added sugars), followed by cold drinks (primarily dairy products) and hot drinks (broths and hot chocolate). Most foods, including salty snacks and hot sandwiches, were high in energy, total fat and SFAs, while drinks were high in sugar. These findings are in agreement with other studies examining the nutritional content of foods sold in vending machines in university [5,6], healthcare [37] and recreational [38] settings, confirming the poor nutritional quality of foods and drinks and the limited number of options that are lower in sugar, fat and saturated fat available from vending machines. Sufficient vending options that support healthy dietary recommendations, with health promotional messaging and with minimal processing should be guaranteed to increase the purchases of products with HNQ from vending machines [12].

With respect to the level of agreement between the two NPMs used, it should be noted that it was almost perfect for total products and for cold and hot drinks; however, 
the lowest level of agreement was obtained for cold/hot foods. These differences in the results obtained from the two NPMs, in the present study, could be related to discrepancies in constructs and scoring criteria for the models used. In fact, UK NPM penalizes high content in sodium, SFA and sugar, but the scores obtained for these products are offset by the positive points associated with the components "fruit, vegetables and nuts" and fibre; a fact that does not happen in the case of the AECOSAN model. Therefore, the percentage of products, in particular, nuts, sweet snacks and cold sandwiches, classified as "with LNP" was higher with AECOSAN's criteria than with UK NMP.

Regarding the differences in nutritional profile according to cost, hot and cold foods and hot drinks with LNQ were consistently less expensive than alternatives with HNQ, while among cold drinks, the results were the reverse (encouragingly, water was often less expensive than soft drinks). The association found between food and drinks with LNQ and high price agrees with the findings of other authors [7,45]. However, not all studies found this association. For example, Ng et al., (2019) did not find statistically significant price differences and argued that this finding might be due to the few options of HNQ available [46]. Various authors have pointed out that the price effects of vending machine products were strong on consumer purchasing patterns [10,19], and when options of HNQ were offered at a reduced cost, the sales of options with HNQ increased [20,47,48]. However, the effects of price and product interventions on profits are still inconclusive $[49,50]$. Concern that price changes would reduce sales and profit may impede managers from offering food and drink choices with HNQ. Therefore, additional studies based on longitudinal data are needed to develop an evidence base concerning the potential effectiveness of pricing interventions among this university community to help improve food consumption patterns.

In addition, products with LNQ were more often promoted, as they were mostly located at the eye and hand levels. These results agree with previous research that showed that food marketing promotes mainly low-nutrition foods and drinks [51]. The layouts and specific product placements that maximise purchases of particular foods in supermarkets have been widely demonstrated to be effective in manipulating buying behaviour [52]. Given the results obtained in this study and data from the literature, we consider it necessary to implement strategies that combine sufficient, price-reduced vending options with HNQ located in strategic spaces to increase purchases of products with HNQ from vending machines. To ensure the implementation of these changes on campus, policies should be implemented, including policies at the European, state and institutional levels.

At the European and state levels, council and governmental regulations could require that all food and drink products offered in higher education institutions meet healthy nutritional criteria, according to current national and international evidence-based nutritional recommendations. Government regulations could guarantee the nutritional quality of the food and drinks offered in universities. At the institutional level, stakeholders, such as decision-makers (e.g., vice management of contracting), food service companies and the university community (students and workers), must be involved in encouraging changes in this regard [5]. After this study, the UPV/EHU implemented some measures to improve the nutritional quality and sustainability of the food and drink products from vending machines [53] through the bid specifications of contracts related to food services. However, difficulties in actually meeting the guidelines and compliance monitoring have been noted since specific plans for monitoring implementation were not provided.

To date, health policy has been developed to improve the availability of food and drinks with HNQ for health facilities [54] and primary and secondary schools [55-57], among others. Currently, in Spain, specific legislation applies to schools [58]. Furthermore, in 2018, the Basque government started a pilot project to increase the number of foods with HNQ in vending machines. This Basque government project set the objective that $50 \%$ of the products offered in schools, hospitals, universities and also in companies should be of HNQ [59]. Additional research is needed to determine whether the presence of items with HNQ in vending machines makes a difference in consumption behaviours when up to $50 \%$ of vending machine items remain of LNQ. In terms of setting vending nutrition/snack 
policies, higher education institutions/employers have been less proactive, and there are no guidelines specifically developed for university settings. Therefore, it is necessary to develop clear policy recommendations specifically for tertiary education settings to guide university administrators to become aware of the issues and to demand change from their vending suppliers. Given the lack of policies of this type in Spain and Europe, those developed and implemented in other countries, such as the United States, could be taken as an example [60,61].

To better contextualise the findings of this research, some limitations need to be acknowledged. First, as data on food and drinks were registered at one point in time, changes in the food supply were not taken into account. However, these changes are usually few in number during the valid period of the supply contract. Second, the sales or consumption of products from vending machines was not assessed; to overcome this limitation, we plan to analyse these data shortly. Despite these limitations, there are several strengths associated with this study. First, to our knowledge, few studies have focused on the nutritional profiles of vending foods and drinks at Spanish universities [25], and none have analysed differences in the nutritional profiles according to price and where products were displayed in vending machines. Second, this research included an analysis of all the vending machines accessible to students and workers of a Spanish public university. Other similar studies assessed only some of the university campuses $[5,6,45]$, which decreases the external validity of the findings. Third, we used a fairly new tool for vending machine assessment studies, digital photography $[13,21]$. This method is highly accurate, reliable and time effective and allows data acquisition for uninterrupted evaluation of the food environment [13,21]. Finally, we applied a tool for the analysis of product promotion that has not been previously used in vending machine assessment studies. This merchandising criterion based on the location of items in the machine could be useful to promote foods and drinks with HNQ.

\section{Conclusions}

Our findings suggest that almost half of the products from vending machines at UPV / EHU were of LNQ, from a nutritional point of view, and almost three-quarters had high levels of processing. Therefore, access to food options with HNQ is limited. Moreover, foods and cold drinks with LNQ were less expensive and more often promoted (i.e., were mostly located at hand or eye level) than alternatives with HNQ. These findings can be useful for developing interventions and policies targeted at improving the healthiness of products from vending machines on campuses, and these environmental changes could make choices with HNQ possible and easier. Future research should focus on the design, implementation and evaluation of intervention strategies and the effect on profits.

Supplementary Materials: The following are available online at https://www.mdpi.com/article/ 10.3390/ijerph18136842/s1, Table S1: Percentages of products classified into the same or opposite category and agreement between the two nutrient profiling models (AECOSAN and UK NPM); Table S2: Percentages of products classified into the same or opposite category and agreement between the two nutrient profiling models (AECOSAN and UK NPM) and the combination of both and processing level classification (NOVA system); Table S3: Simple linear regression analyses examining price by NPMs of products offered on vending machines on campus; Table S4: Binary logistic regression analyses examining promotion by NPMs of products offered on vending machines on campus.

Author Contributions: N.M.-P. acquired and analysed the data; N.M.-P. and M.A.-I. interpreted the results, drafted the manuscript and contributed to the conception and design (including methodology) of the research and to the funding acquisition. M.A.-I. was responsible for project administration and supervision. All authors have read and agreed to the published version of the manuscript. 
Funding: This project was supported by the Vice Rector for Students and Employability of the UPV/EHU and Basque Government (2016); and the Vice Rector for Innovation, Social Outreach and Cultural Activities of the UPV/EHU (funding by the contract programme formalised with the Basque government) (grant numbers of the Campus Bizia Lab project: 17ARRO, 18ARRO, 19ARRO and 20ARRO). Open Access funding provided by the Department of Nursing of the UPV/EHU and the project Campus Bizia Lab 20ARRO.

Institutional Review Board Statement: Not applicable.

Informed Consent Statement: Not applicable.

Data Availability Statement: Data are to be made available only via a request to the corresponding author. Data will be provided only after the acceptance and signature of a formal data sharing agreement.

Acknowledgments: The authors want to particularly acknowledge all the researchers (by alphabetical order according to the first surname) of the projects that funded this investigation for its collaboration: L Ansotegui Alday, MD Basabe Barañano, N Bermudez Marín, MD Encinas Malagón, L García Iruretagoyena, I Hernández Pintor, P Insúa Cerretani, M Mtz. de Pancorbo, SG Padoan Moura, E Rebato Ochoa, AM Rocandio Pablo, N Telleria-Aramburu and S Telletxea Artzamendi.

Conflicts of Interest: The authors declare no conflict of interest.

\section{References}

1. World Health Organization. Obesity and Overweight. 2020. Available online: https://www.who.int/news-room/fact-sheets/ detail/obesity-and-overweight (accessed on 15 February 2021).

2. French, S.A.; Story, M.; Jeffery, R.W. Environmental influences on eating and physical activity. Annu. Rev. Public Health 2001, 22, 309-335. [CrossRef] [PubMed]

3. McAlister, A.L.; Perry, C.L.; Parcel, G.S. How individuals, environments, and health behaviors interact: Social cognitive theory. In Health Behavior and Health Education: Theory, Research, and Practice; Glanz, K., Rimer, B.K., Viswanath, K., Eds.; Jossey-Bass: San Francisco, CA, USA, 2008; pp. 169-188.

4. Roy, R.; Kelly, B.; Rangan, A.; Allman-Farinelli, M. Food Environment Interventions to Improve the Dietary Behavior of Young Adults in Tertiary Education Settings: A Systematic Literature Review. J. Acad. Nutr. Diet. 2015, 115, 1647-1681.e1. [CrossRef] [PubMed]

5. $\quad$ Byrd-Bredbenner, C.; Johnson, M.; Quick, V.M.; Walsh, J.; Greene, G.W.; Hoerr, S.; Colby, S.M.; Kattelmann, K.K.; Phillips, B.W.; Kidd, T.; et al. Sweet and salty. An assessment of the snacks and beverages sold in vending machines on US post-secondary institution campuses. Appetite 2012, 58, 1143-1151. [CrossRef]

6. Park, H.; Papadaki, A. Nutritional value of foods sold in vending machines in a UK University: Formative, cross-sectional research to inform an environmental intervention. Appetite 2016, 96, 517-525. [CrossRef]

7. Grech, A.; Hebden, L.; Roy, R.; Allman-Farinelli, M. Are products sold in university vending machines nutritionally poor? A food environment audit. Nutr. Diet. 2017, 74, 185-190. [CrossRef]

8. Velazquez, C.E.; Black, J.L.; Potvin Kent, M. Food and Beverage Marketing in Schools: A Review of the Evidence. Int. J. Environ. Res. Public Health 2017, 14, 1054. [CrossRef] [PubMed]

9. Contento, I.R. Nutrition education: Linking research, theory, and practice. Asia Pac. J. Clin. Nutr. 2008, 17 (Suppl. S1), 176-179.

10. Grech, A.; Allman-Farinelli, M. A systematic literature review of nutrition interventions in vending machines that encourage consumers to make healthier choices. Obes. Rev. 2015, 16, 1030-1041. [CrossRef]

11. Carrad, A.M.; Louie, J.C.; Milosavljevic, M.; Kelly, B.; Flood, V.M. Consumer support for healthy food and drink vending machines in public places. Aust. N. Z. J. Public Health 2015, 39, 355-357. [CrossRef]

12. Hua, S.V.; Ickovics, J.R. Vending Machines: A Narrative Review of Factors Influencing Items Purchased. J. Acad. Nutr. Diet. 2016, 116, 1578-1588. [CrossRef]

13. Horacek, T.M.; Yildirim, E.D.; Matthews Schreiber, M.; Byrd-Bredbenner, C.; Colby, S.; White, A.A.; Shelnutt, K.P.; Olfert, M.D.; Mathews, A.E.; Riggsbee, K.; et al. Development and Validation of the Vending Evaluation for Nutrient-Density (VEND)ing Audit. Int. J. Environ. Res. Public Health 2019, 16, 514. [CrossRef]

14. Whatnall, M.C.; Ng, H.S.; Liau, C.Y.; Patterson, A.J.; Hutchesson, M.J. What is the nutritional value of food and drinks sold in vending machines at an Australian university? A food environment audit study. Nutr. Diet. 2020, 77, 550-552. [CrossRef] [PubMed]

15. Kvaavik, E.; Andersen, L.F.; Klepp, K.I. The stability of soft drinks intake from adolescence to adult age and the association between long-term consumption of soft drinks and lifestyle factors and body weight. Public Health Nutr. 2005, 8, 149-157. [CrossRef] [PubMed]

16. Eurostat Statistics Explained. Tertiary Education Statistics. Available online: https://ec.europa.eu/eurostat/statistics-explained/ index.php/Tertiary_education_statistics (accessed on 15 February 2021). 
17. Eurostat Statistics Explained. Educational Attainment Statistics. Available online: https://ec.europa.eu/eurostat/statisticsexplained/index.php/Educational_attainment_statistics (accessed on 15 February 2021).

18. Matthews, M.A.; Horacek, T.M. Vending machine assessment methodology. Appetite 2015, 90, 176-186. [CrossRef] [PubMed]

19. Callaghan, C.; Gillian Mandich, G.; He, M. Healthier snacks in school vending machines: A pilot project in four Ontario high schools. Can. J. Diet. Pract. Res. 2010, 71, 186-191. [CrossRef]

20. Kocken, P.L.; Eeuwijk, J.; Van Kesteren, N.M.; Dusseldorp, E.; Buijs, G.; Bassa-Dafesh, Z.; Snel, J. Promoting the purchase of lowcalorie foods from school vending machines: A cluster-randomized controlled study. J. Sch. Health 2012, 82, 115-122. [CrossRef]

21. Matthews, M.; Horacek, T.M.; Olfert, M.D.; Koenings, M.M.; Shelnutt, K.P.; Stocker, C.; Golem, D.L.; Kattelmann, K.K.; Colby, D.; Franzen-Castle, L.; et al. Development, Validation and Implementation of the Health Density Vending Machine Audit Tool (HDVMAT). J. Acad. Nutr. Diet. 2014, 114, A65. [CrossRef]

22. Minaker, L.M.; Storey, K.E.; Raine, K.D.; Spence, J.C.; Forbes, L.E.; Plotnikoff, R.C.; McCargar, L.J. Associations between the perceived presence of vending machines and food and beverage logos in schools and adolescents' diet and weight status. Public Health Nutr. 2011, 14, 1350-1356. [CrossRef]

23. Raposo, A.; Carrascosa, C.; Pérez, E.; Saavedra, P.; Sanjuán, E.; Millán, R. Vending machines: Food safety and quality assessment focused on food handlers and the variables involved in the industry. Food Control 2015, 56, 177-185. [CrossRef]

24. European Vending \& Cofee Service Association (EVA). Available online: https://www.vending-europe.eu/ (accessed on 3 June 2021).

25. Martin Payo, R.; Sánchez Díaz, C.; Suarez Colunga, M.; García García, R.; Blanco Díaz, M.; Fernández Álvarez, M.D.M. Composición nutricional de los alimentos de las vending de edificios públicos universitarios y hospitalarios de Asturias [Nutritional composition of vending foods of public university and hospital buildings in Asturias]. Aten. Primaria 2020, 52, 22-28. [CrossRef]

26. Agencia Española de Consumo, Seguridad alimentaria y Nutrición. Documento de Consenso sobre la Alimentación en los Centros Educativos. 2010. Available online: https:/ /www.aesan.gob.es/AECOSAN/docs/documentos/nutricion/educanaos/ documento_consenso.pdf (accessed on 15 February 2021).

27. Dunford, E.; Webster, J.; Metzler, A.B.; Czernichow, S.; Mhurchu, C.N.; Wolmarans, P.; Snowdon, W.; L'Abbe, M.; Li, N.; Maulik, P.K.; et al. International collaborative project to compare and monitor thenutritional composition of processed foods. Eur. J. Prev. Cardiol. 2012, 19, 1326-1332. [CrossRef]

28. Ortega, R.M.; López-Sobaler, A.M.; Andrés, P.; Requejo, A.M.; Aparicio, A.; Molinero, L.M. Programa DIAL Para Valoración de Dietas y Cálculos de Alimentación (Para Windows, Versión 2.12); Departamento de Nutrición (UCM) \& Alce Ingeniería, S.L: Madrid, Spain, 2016.

29. Mataix, J. Tabla de Composición de Alimentos, 5th ed.; Universidad de Granada: Granada, Spain, 2009.

30. Agencia Española de Consumo, Seguridad Alimentaria y Nutrición. Contenido de Ácidos Grasos Trans en los Alimentos en España, 2015. 2016. Available online: http://www.aesan.gob.es/AECOSAN/docs/documentos/nutricion/Informe_AGT2015 pdf (accessed on 15 February 2021).

31. National Agricultural Library. USDA Food Composition Databases. Available online: https://fdc.nal.usda.gov/ (accessed on 15 February 2021).

32. Department of Health of the United Kingdom. Nutrient Profiling Technical Guidance. 2011. Available online: https://assets. publishing.service.gov.uk/government/uploads/system/uploads/attachment_data/file/216094/dh_123492.pdf (accessed on 15 February 2021).

33. Labonté, M.E.; Poon, T.; Gladanac, B.; Ahmed, M.; Franco-Arellano, B.; Rayner, M.; L'Abbé, M.R. Nutrient Profile Models with Applications in Government-Led Nutrition Policies Aimed at Health Promotion and Noncommunicable Disease Prevention: A Systematic Review. Adv. Nutr. 2018, 9, 741-788. [CrossRef]

34. Monteiro, C.A.; Cannon, G.; Moubarac, J.C.; Levy, R.B.; Louzada, M.; Jaime, P.C. The UN Decade of Nutrition, the NOVA food classification and the trouble with ultra-processing. Public Health Nutr. 2018, 21, 5-17. [CrossRef] [PubMed]

35. Instituto Datakey. Merchandising: Definición y Función Del Lineal; Instituto Datakey: Donostia, Spain, 2014; Available online: http:/ / www.instituto-datakey.com/1025/ (accessed on 15 February 2021).

36. Landis, J.R.; Koch, G.G. The Measurement of observer agreement for categorical data. Biometrics 1977, 33, 159-174. [CrossRef]

37. Kibblewhite, S.; Bowker, S.; Jenkins, H.R. Vending machines in hospitals-Are they healthy? Nutr. Food Sci. 2010, 40, 26-28. [CrossRef]

38. Naylor, P.J.; Bridgewater, L.; Purcell, M.; Ostry, A.; Wekken, S.V. Publically funded recreation facilities: Obesogenic environments for children and families? Int. J. Environ. Res. Public Health 2010, 7, 2208-2221. [CrossRef]

39. Luiten, C.M.; Steenhuis, I.H.; Eyles, H.; Ni Mhurchu, C.; Waterlander, W.E. Ultra-processed foods have the worst nutrient profile, yet they are the most available packaged products in a sample of New Zealand supermarkets. Public Health Nutr. 2016, 19, 530-538. [CrossRef]

40. Lawrence, S.; Boyle, M.; Craypo, L.; Samuels, S. The food and beverage vending environment in health care facilities participating in the healthy eating, active communities program. Pediatrics 2009, 123 (Suppl. S5), S287-S292. [CrossRef]

41. Popp, J. Breaking the molds: Noncommercial sectors adopt new strategies, tactics and thinking to survive and grow. Restaur. Ins. 2005, 38. Available online: http://images.centralrestaurant.com/images/trends/pdfs/breaking_moldsRI.pdf (accessed on 3 May 2021). 
42. Hartstein, J.; Cullen, K.W.; Virus, A.; El Ghormli, L.; Volpe, S.L.; Staten, M.A.; Bridgman, J.C.; Stadler, D.D.; Gillis, B.; McCormick, S.B.; et al. Impact of the HEALTHY Study on Vending Machine Offerings in Middle Schools. Child Nutr. Manag. 2011, $35,16353$.

43. Brown, M.V.; Flint, M.; Fuqua, J. The effects of a nutrition education intervention on vending machine sales on a university campus. J. Am. Coll. Health 2014, 62, 512-516. [CrossRef]

44. Alfred Health. A Green Light for Healthy Consumption. 2015. Available online: http://heas.health.vic.gov.au/sites/default/ files / Alfred\%20Health\%20-\%20red\%20drinks\%20off\%20display\%20FINAL.pdf (accessed on 17 September 2016).

45. Lee, A.; Mhurchu, C.N.; Sacks, G.; Swinburn, B.; Snowdon, W.; Vandevijvere, S.; Hawkes, C.; L'abbé, M.; Rayner, M.; Sanders, D.; et al. Monitoring the price and affordability of foods and diets globally. Obes. Rev. 2013, 14 (Suppl. S1), 8295. [CrossRef] [PubMed]

46. Ng, K.W.; Sangster, J.; Priestly, J. Assessing the availability, price, nutritional value and consumer views about foods and beverages from vending machines across university campuses in regional New South Wales, Australia. Health Promot. J. Austr. 2019, 30, 76-82. [CrossRef]

47. French, S.A.; Jeffery, R.W.; Story, M.; Breitlow, K.K.; Baxter, J.S.; Hannan, P.; Snyder, M.P. Pricing and promotion effects on low-fat vending snack purchases: The CHIPS Study. Am. J. Public Health 2001, 91, 112-117. [CrossRef]

48. Whatnall, M.C.; Patterson, A.J.; Hutchesson, M.J. Effectiveness of Nutrition Interventions in Vending Machines to Encourage the Purchase and Consumption of Healthier Food and Drinks in the University Setting: A Systematic Review. Nutrients 2020, $12,876$. [CrossRef] [PubMed]

49. Viana, J.; Leonard, S.A.; Kitay, B.; Ansel, D.; Angelis, P.; Slusser, W. Healthier vending machines in a university setting: Effective and financially sustainable. Appetite 2018, 121, 263-267. [CrossRef]

50. Pharis, M.L.; Colby, L.; Wagner, A.; Mallya, G. Sales of healthy snacks and beverages following the implementation of healthy vending standards in City of Philadelphia vending machines. Public Health Nutr. 2018, 21, 339-345. [CrossRef]

51. Cairns, G.; Angus, K.; Hastings, G.; Caraher, M. Systematic reviews of the evidence on the nature, extent and effects of food marketing to children. A retrospective summary. Appetite 2013, 62, 209-215. [CrossRef] [PubMed]

52. Stanton, R.A. Food Retailers and Obesity. Curr. Obes. Rep. 2015, 4, 54-59. [CrossRef]

53. UPV/EHU. Solicitud de Expediente-Anexos. Pautas e Instrucciones. Ley 9/2017 de Contratos del Sector Público. 2019. Available online: https: / www.ehu.eus/documents/1180425/10189353/2.12.20+Pautas+e+Instrucciones.pdf/5f2515eb-12bf9744-fc16-d8fd41cbcde8?t=1606907347257 (accessed on 15 February 2021).

54. Ministry of Health NSW. Live Life Well @ Health: Healthier Food \& Drink Choices—Staff \& Visitors in NSW Health Facilities. Australia. 2009. Available online: http://www0.health.nsw.gov.au/policies/pd/2009/pdf/PD2009_081.pdf (accessed on 9 September 2016).

55. Mozaffarian, D. Dietary and Policy Priorities for Cardiovascular Disease, Diabetes, and Obesity: A Comprehensive Review. Circulation 2016, 133, 187-225. [CrossRef]

56. Orava, T.; Manske, S.; Hanning, R. Beverages and snacks available in vending machines from a subset of Ontario secondary schools: Do offerings align with provincial nutrition standards? Can. J. Public Health 2016, 107, e417-e423. [CrossRef] [PubMed]

57. Vine, M.M.; Harrington, D.W.; Butler, A.; Patte, K.; Godin, K.; Leatherdale, S.T. Compliance with school nutrition policies in Ontario and Alberta: An assessment of secondary school vending machine data from the COMPASS study. Can. J. Public Health 2017, 108, e43-e48. [CrossRef]

58. Law 17/2011, of July 5, of Food Safety and Nutrition. Boletín Oficial del Estado. 6 July 2011. N ${ }^{\circ} 160$. Available online: https: //www.boe.es/eli/es/1/2011/07/05/17/dof/spa/pdf (accessed on 15 February 2021).

59. Basque Government. INITIATIVES FOR HEALTHY EATING HABITS IN THE BASQUE COUNTRY; Servicio Central de Publicaciones del Gobierno Vasco: Vitoria-Gasteiz, Spain, 2018. Available online: https:/ /www.euskadi.eus/web01-a2aznscp/ es/k75aWebPublicacionesWar/k75aObtenerPublicacionDigitalServlet?R01HNoPortal=true\&N_LIBR=052129\&N_EDIC=0001 $\&$ C_IDIOM=en\&FORMATO=.pdf (accessed on 15 February 2021).

60. Wickramasekaran, R.N.; Robles, B.; Dewey, G.; Kuo, T. Evaluating the Potential Health and Revenue Outcomes of a 100\% Healthy Vending Machine Nutrition Policy at a Large Agency in Los Angeles County, 2013-2015. J. Public Health Manag. Pract. 2018, 24, 215-224. [CrossRef] [PubMed]

61. University of California, Global Food Initiative. UC Healthy Vending Policy. Implementation \& Best Practices Toolkit. 2018. Available online: https://www.ucop.edu/global-food-initiative/_files/uc-healthy-vending-toolkit-final-for-dissemination.pdf (accessed on 3 June 2021). 